\title{
TAXONOMY OF THREE TAXA OF BULBOCHAETE C. AG. AND PHYSICO-CHEMICAL ANALYSIS OF WATER IN WEST BENGAL, INDIA
}

\author{
Nilu Halder \\ Department of Botany, Raja Peary Mohan College \\ Uttarpara-712258, Hooghly, West Bengal, India \\ Email: niluhalder75@gmail.com
}

\begin{abstract}
In the present paper, altogether three algal taxa of genus Bulbochaete C. Ag. (Oedogoniales, Chlorophyceae) viz. Bulbochaete elatior f. pumila Hirn, Bulbochaete pseudoelatior Jao and Bulbochaete triangularis var. bengalensis J.P. Keshri have been morpho-taxonomically described with physico-chemical characterization of water and some additional information. These algal samples were collected as epiphytic conditions on submerged stems of angiospermic plants from two freshwater ponds in Hooghly district, West Bengal, India. All these three species are new records from this region. They were greenish, nannandrous, gynandrosporous or idioandrosporous. Most importantly, phenotypically their oospore shape was more or less alike as oogonium. The results of analyses of physico-chemical parameters of water showed that $\mathrm{pH}$ ranged from 7.2-7.4 (alkaline). The primary nutrients like nitrate-nitrogen $\left(\mathrm{NO}_{3}-\mathrm{N}\right)$ and phosphate $\left(\mathrm{PO}_{4}{ }^{3-}\right)$ values were measured in lower amounts $(0.15-0.17 \mathrm{mg} / \mathrm{l}$ and $0.23-0.24 \mathrm{mg} / \mathrm{l}$, respectively) which affected Bulbochaete growth and diversity in the lentic water bodies. It was interesting to note that winter season was suitable for their occurrences.
\end{abstract}

Key words: Taxonomy, Bulbochaete C. Ag., Physico-chemical characterization.

\section{INTRODUCTION}

Bulbochaete C. Ag. exhibits greatest complexity in the vegetative and reproductive structural organizations in the order Oedogoniales of the class Chlorophyceae (Cook 1962). It was Pringsheim (1858) who first identified and described the life cycle pattern of this genus. The thallus of Bulbochaete C. Ag. is composed of extensive unilateral and uniseriate branched filaments whose some of the cells (apical or interstitial cells) bear setae with bulbous bases. This is a unique feature that differs the genus from other Oedogoniale members. The alga is found attached to the aquatic angiospermic plants as epiphyte (Dhande 2014) like that of Coleochaete Bréb. (Halder 2015). Asexual reproduction is characterized by the formation of a multiflagellate zoospore within zoosporangium (Retallack and Butler 1970). Sexual reproduction is oogamous. Zygote is thick walled and sometimes ornamented. 
As algae grow naturally in water bodies and limnological study has a great importance in the ecological and floristic work of algal flora hence, different important physico-chemical parameters viz. temperature $\left({ }^{\circ} \mathrm{C}\right), \mathrm{pH}$, nitrate-nitrogen $\left(\mathrm{NO}_{3}\right.$ $\mathrm{N}$ ), phosphate $\left(\mathrm{PO}_{4}{ }^{3-}\right)$, dissolved oxygen (DO), biochemical oxygen demand (BOD), chemical oxygen demand (COD), total dissolved solids (TDS), sulphate $\left(\mathrm{SO}_{4}{ }^{2-}\right)$ and salinity of waters of the sampling sites were measured.

Survey of review of literature on the genus Bulbochaete C. Ag. showed that few taxonomic investigations were carried out from West Bengal and India. In this respect, some noteworthy publications were those of Kamat (1962) from Gujarat; Gonzalves (1962), Gonzalves and Jain (1970), Dhande et al. (2014) from Maharashtra; Prasad and Fatma (1981), Shukla and Tiwari (1986), Shukla et al. (1986), Habib and Pandey (1989), Srivastava and Misra (2009) from Uttar Pradesh; Mahato and Mahato (1999) from Jharkhand; Kargupta and Sarma (1987), Sarma et al. (1988), Kargupta (1996), Kargupta et al. (1997), Keshri (2008) from West Bengal, India.

Taxonomic study is one and only procedure for identification, classification and assessment of biodiversity of living organisms (Guerra-García et al. 2008). The biodiversity of algal flora is being lost at an unprecedented rate in this locality due to several anthropogenic activities like infrastructural developmental projects, urbanization, industrialization, expansion of road and rail line track to some extent and water pollution (Halder and Sinha 2015). Therefore, this type of work is needed for exploration and documentation of species that exist in a particular ecosphere. This work was undertaken with the objectives to study morphological characteristics of the species of Bulbochaete C. Ag. in respect of ecology, phenology, significance and world wide distribution.

\section{MATERIALS AND METHODS}

Algal samples were collected in plastic and glass containers from fresh water habitats at Chandannagar $\left(22^{\circ} .85^{\prime} \mathrm{N} ; 8^{\circ} .36^{\prime} \mathrm{E}\right)$, Baidyabati $\left(22^{\circ} .79^{\prime} \mathrm{N} ; 88^{\circ} .31^{\prime} \mathrm{E}\right)$ of Hooghly district, West Bengal, India (Fig. 1) during the period of 20092010 in winter season. Detailed taxonomic study was made by examining the algal specimens under Olympus microscope (Model-CH20i). Microphotographs were taken using Canon Power Shot A480 camera. The samples were preserved in $4 \%$ formalin and the voucher specimens were deposited in the Departmental Herbarium of R.P.M. College, Uttarpara, Hooghly, West Bengal. Identification of the taxa accomplished with the help of authentic literature (Gonzalvales and Sonad 1957, Aziz et al. 1991, Naz et al. 2008, Keshri 2008). Analysis of limnological parameters was made following the procedures prescribed earlier (Halder 2015a, b) and salinity was measured by hand refractometer (Atago, Japan).

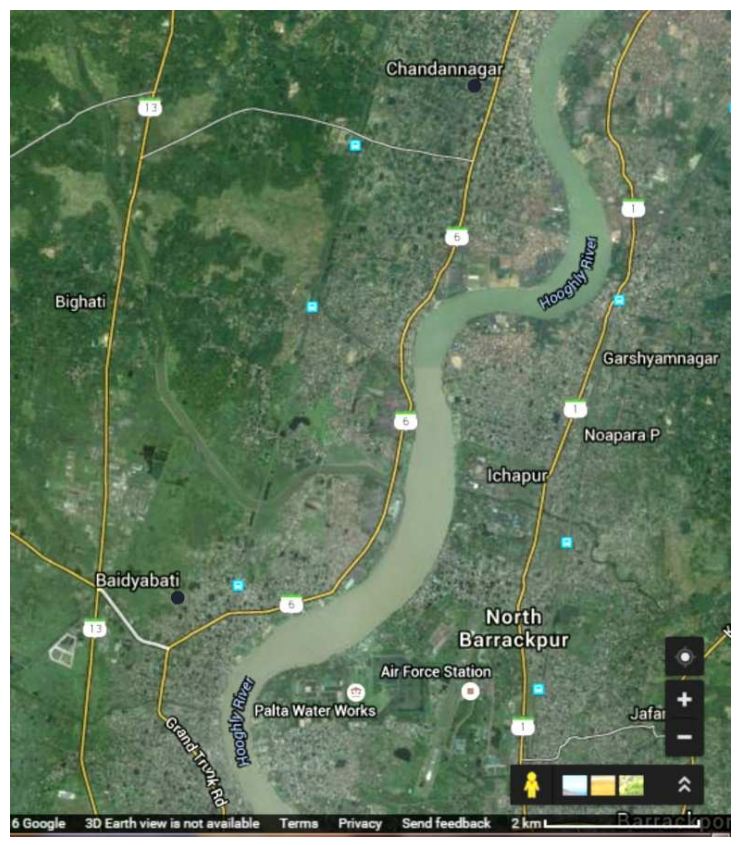

Fig. 1. (•indicated collection sites in the Google map) 


\section{RESULTS AND DISCUSSION}

A total number of three Bulbochaete C. Ag. taxa namely Bulbochaete elatior f. pumila Hirn, Bulbochaete pseudoelatior Jao and Bulbochaete triangularis var. bengalensis J.P. Keshri belonging to the order Oedogoniale of the class Chlorophyceae had been described along with some additional information for the first time.

\section{TAXONOMIC TREATMENTS}

Class Chlorophyceae; Order: Oedogoniale

Genus: Bulbochaete C. Ag.

Bulbochaete elatior f. pumila Hirn in Monogr. Oedogon. 322: pl. L1, fig. 328, 1900; Naz et al. in Bangladesh J. Plant Taxon. 15(2): 82-83, 85, pl.1, fig. 3; pl.2, fig. 2, 2008. (Fig. 2A)

Taxonomic features: Thallus nannandrous, gynandrosporous; plant short, arcuate, well branched; vegetative cells shorter, cylindricarcuate; 30.0-35.0 $\mu \mathrm{m}$ long, 14.0-17.0 $\mu \mathrm{m}$ broad; oogonium depressed- globose to sub-quadrangular globose and erect; 34.0-36.0 $\mu \mathrm{m}$ long, 37.0-43.0 $\mu \mathrm{m}$ broad; oospore shape same as oogonium and orange, filling the oogonium; outer spore wall smooth; 29.0-33.0 $\mu \mathrm{m}$ long, 33.0-39.0 $\mu \mathrm{m}$ broad; androsporangium single, epigynous; $10.0-12.0 \mu \mathrm{m}$ long, 12.0-13.5 $\mu \mathrm{m}$ broad.

Habitat: It occurred in a pond at Baidyabati, Hooghly district, West Bengal, India.

Collection no. and date: NH 613 (20-11-2009); Phenology: November to February (winter).

Ecological significance: It acts as a primary producer in pond.

Species abundance: It was abundant in most water bodies.

Conservation status: The conservation status is least concern (LC) from this state.
Distribution: South America, Brazil, South-West Asia like India and Bangladesh.

Bulbochaete pseudoelatior Jao in Bull. Bot. Acad. Sinica 1: 94, fig. 1, 1, 1947. (Fig. 2B)

Taxonomic features: Plant dioecious, nannandrous, idioandrosporous; well branched; vegetative cells 12.0-25.0 $\mu \mathrm{m}$ long, 9.0-12.0 $\mu \mathrm{m}$ broad; suffultory or supporting cell 10.0-16.0 $\mu \mathrm{m}$ long, 8.5-8.8 $\mu \mathrm{m}$ broad; oogonium sub-quadrangular to globose, oospore completely filling the oogonium; 20.5$21.5 \mu \mathrm{m}$ long, 22.0-25.5 $\mu \mathrm{m}$ broad; androsporangium 7.6-9.5 $\mu \mathrm{m}$ long, 7.5-8.5 $\mu \mathrm{m}$ broad.

Habitat: In pond at Baidyabati, Hooghly district, West Bengal.

Collection no. and date: NH 613 (18-11-2009); Phenology: December to March.

Ecological significance: Acts as a primary producer in the ponds.

Species abundance: Sparse; Conservation status: Near threatened (NT).

Distribution: South-West Asia like India and Bangladesh.

Bulbochaete triangularis var. bengalensis J.P. Keshri in Biblioth. Phycol. 114: 37, pl.8, figs. 33, 34, 2008 (Fig. 2C)

Taxonomic features: Plant dioecious, nannandrous, idioandrosporous; well branched; vegetative cells 28.0-35.5 $\mu \mathrm{m}$ long, 14.5-16.5 $\mu \mathrm{m}$ broad; oogonium sub-depressed to subtriangular-globose, two sides slightly convex, angles rounded; 38.0-40.0 $\mu \mathrm{m}$ long, 40.0-45.0 $\mu \mathrm{m}$ broad; oospore shape similar to oogonium, completely filling the oogonium; 34.0$38.0 \mu \mathrm{m}$ long, 36.0-42.0 $\mu \mathrm{m}$ broad; spore wall thick; androsporangium epigynous; $11.0-15.0 \mu \mathrm{m}$ long, $10.0-13.0 \mu \mathrm{m}$ broad.

Habitat: In a pond at Chandannagar, Hooghly district, West Bengal, India. 
Collection no. and date: NH 621 (18-01-2010); Phenology: January to April.

Ecological significance: Acts as a primary producer in pond.

Species abundance: Rare; Conservation status: Data deficient (DD)

Distribution: South-West Asia like India.

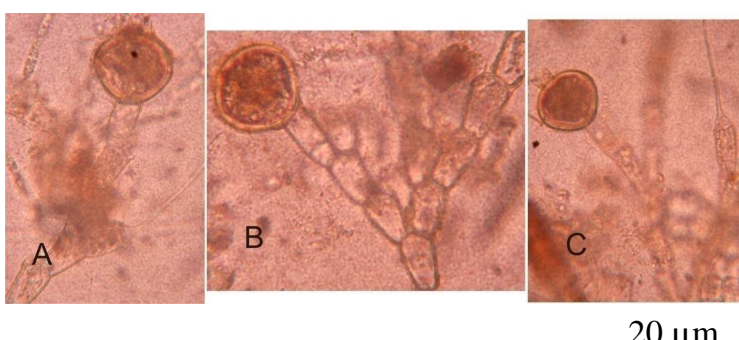

Fig. 2 (A-C). (A) Bulbochaete elatior f. pumila,

(B) Bulbochaete pseudoelatior,

(C) Bulbochaete triangularis var. bengalensis.

Table 1. Physico-chemical characteristics of water in ponds during the algae sampling times $($ Mean \pm SE)

\begin{tabular}{lcc}
\hline $\begin{array}{l}\text { Physico-chemical } \\
\text { parameters }\end{array}$ & $\begin{array}{c}\text { Pond water } \\
\text { at } \\
\text { Baidyabati, } \\
\text { Hooghly }\end{array}$ & $\begin{array}{c}\text { Pond water at } \\
\text { Chandannagar, } \\
\text { Hooghly }\end{array}$ \\
\hline Temp. ( $\left.{ }^{\circ} \mathrm{C}\right)$ & $21 \pm 0.14$ & $19 \pm 0.13$ \\
$\mathrm{pH}$ & $7.2 \pm 0.05$ & $7.4 \pm 0.05$ \\
$\mathrm{DO}(\mathrm{mg} / 1)$ & $8.2 \pm 0.11$ & $8.0 \pm 0.12$ \\
$\mathrm{BOD}(\mathrm{mg} / 1)$ & $3.2 \pm 0.05$ & $3.8 \pm 0.11$ \\
$\mathrm{COD}(\mathrm{mg} / 1)$ & $90.0 \pm 5.77$ & $90.0 \pm 2.5$ \\
$\mathrm{NO}_{3}-\mathrm{N}(\mathrm{mg} / 1)$ & $0.15 \pm 0.05$ & $0.17 \pm 0.05$ \\
$\mathrm{PO}_{4}{ }^{3-}(\mathrm{mg} / 1)$ & $0.24 \pm 0.11$ & $0.23 \pm 0.12$ \\
$\mathrm{TDS}(\mathrm{mg} / 1)$ & $122.0 \pm 0.20$ & $128.0 \pm 0.20$ \\
$\mathrm{SO}_{4}{ }^{2-}(\mathrm{mg} / 1)$ & $6.8 \pm 0.22$ & $7.0 \pm 0.17$ \\
$\mathrm{Salinity}(\mathrm{ppt})^{\mathrm{A}}$ & $0.3 \pm 0.01$ & $0.2 \pm 0.01$ \\
\hline
\end{tabular}

All the parameters are in triplicate values with mean value \pm standard error.

Among the three taxa, Bulbochaete elatior Pringsheim ex Hirn was first reported by Carter
(1926) from India. Following the pioneer work, Sarma (1962) and Khan (1970) from Uttar Pradesh; Gonzalves and Sonad (1957) from Karnataka and Kargupta (1996) from West Bengal, India have reviewed the species. The present forma comes close to the species but it is exactly resembled with the $B$. elatior f. pumila Hirn in all the characteristics like description and measurement of vegetative and reproductive organs while, the present taxonomic study of Bulbochaete pseudoelatior Jao and Bulbochaete triangularis var. bengalensis (as bengalense) J.P. Keshri confirmed the earlier finding (Keshri 2008). Thus, the taxonomic study exhibited that Bulbochaete pseudoelatior Jao and Bulbochaete triangularis var. bengalensis J.P Keshri were the second report from India.

The previous workers mainly described the morpho-taxonomic features of those taxa excluding analysis of physico-chemical characterization of water. In this work, emphasis had been given on both taxonomy as well as limnology to describe the species. Species composition, presence and growth of algal species were regulated by several abiotic factors such as temperature, nutrients and salinity of water (Agadi and Untawale 1978, Mikulski 1982, Siva and Sugumaran 2013). This observation was also encountered in this investigation.

The physico-chemical properties of waters of study sites during algae sampling are given in Table 1. In the present work, the results of analyses of water showed that the species were grown in $\mathrm{pH}$ ranged from 7.2-7.4 that reflected alkalinity of water. Dissolved oxygen (DO) content of water was recorded as 8.0-8.2 mg/l which was good due to growing some floating aquatic weeds in these ponds. Nitrate-nitrogen $\left(\mathrm{NO}_{3}-\mathrm{N}\right)$ and phosphate $\left(\mathrm{PO}_{4}{ }^{3-}\right)$ values were determined between 0.15-0.17 $\mathrm{mg} / \mathrm{l}$ and $0.23-0.24 \mathrm{mg} / \mathrm{l}$, respectively which were found suitable for their growth. Chemical oxygen demand (COD), total dissolved solids (TDS) and sulphate $\left(\mathrm{SO}_{4}{ }^{2-}\right)$ were found within the prescribed

ECOPRINT VOL 23, 2016 
limit of WHO (2011). Salinity is a measurement of anions and cations composition of water and it is less in freshwater in comparison to estuarine and coastal water. Relatively, low value of salinity was determined as 0.2-0.3 ppt in these water bodies. The present study also agrees well with earlier reports of water analysis by the author/s during floristic study of algal flora from this district in West Bengal, India (Halder 2015b, Sinha and Halder 2014, Halder and Sinha 2014). Water temperature is considered to be one of the important factors in the periodicity of algae (Juneja et al. 2013). In this work, this statement was found to be true and the occurrences of all these species were observed in the winter season while onset of summer was responsible for their disappearances.

Therefore, the taxonomic study exhibited that species of Bulbochaete C. Ag. showed some variations in morphological features and phenologies. This limnological study indicated that all those major parameters supported the growth and development of those species as well as they could be used as bioindicator of water quality. In addition to that, pond water was found to be less polluted and could be used for domestic purposes (not for drinking), agricultural activities, pisciculture and water bodies could be categorized as oligotrophic nature. The present study also showed that the species of Bulbochaete C. Ag. grow in freshwater in winter season as epiphytes and they were found till early summer.

\section{REFERENCES}

Agadi, V.V. and A.G. Untawale. 1978. Marine algal flora of Goa coast seaweed. Res. Util. 3(1\& 2):56-70.

Aziz, A., J. Alam and A.K.M.N. Islam. 1991. Studies on the members of Oedogoniales epiphytic on deep water rice plants near Sonargaon, Bangladesh. Dhaka Univ. Stud. 6:119-123.
Carter, N. 1926. Fresh water algae from India. Rec. Bot. Surv. India 9:263-302.

Cook, P.W. 1962. Growth and reproduction of Bulbochaete hiloensis in unialgal culture. Trans. Am. Microsc. Soc. 81:384-395.

Dhande, J.S., A.K. Jawale, and S.A. Patil. 2014. Oedogoniaceae from Jalgaon district, Maharashtra- Oedogonium (Link) Hirn and Bulbochaete (Ag.) Hirn. CibTech. J. BioProtocols 3(3):27-32.

Gonzalves, E.A. 1962. A new dioecious macrandrous species of Bulbochaete. Phytomorphol. 12:74-76.

Gonzalves, E.A. and G.R. Sonad. 1957. The genus Bulbochaete in western India. J. Univ. Bombay 25:1-15.

Gonzalves, E.A. and S.C. Jain. 1970. Some Oedogoniaceae from Thana district. Phykos 9(1):1-16.

Guerra-García, J.M., F. Espinosa and J.C. GarcíaGómez. 2008. Trends in taxonomy today:An overview about the main topics in taxonomy. Zool. Baetica 19:15-49.

Habib, I. and V.C. Pandey. 1989. On the occurrence of Bulbochaete spp. from Bareilly (India). Indian Bot. Contractor 6(3):103-104.

Halder, N. 2015a. Taxonomy and ecology of Coleochaete irregularis Pringsheim and Coleochaete orbicularis Pringsheim, West Bengal, India. J. Algal Biomass Utln. 6(4):4749.

Halder, N. 2015b. Morpho-taxonomy of Hydrodictyon reticulatum (L.) Lagerheim and Pediastrum tetras var. tetraodon (Corda) Hansgirg, Hooghly, West Bengal, India. Tropical Plant Res. 2(3):168-171.

Halder, N. and S.N. Sinha. 2014. New records of Euglena acus (O.F. Müll.) Ehr. and Phacus acuminatus (A. Stokes) Huber-Pestalozzi of Euglenineae from Hooghly District, West Bengal. JAIR 3(7):333-336.

Halder, N. and S.N. Sinha. 2015. New report of the occurrence of four Chlorophycean algal 
species from West Bengal, India. J. Algal Biomass Utln. 6(3):20-23.

Juneja, A., R.M. Ceballos and G.S. Murthy. 2013. Effects of environmental factors and nutrient availability on the biochemical composition of algae for biofuels production: A review. Energies 6:4607-4638.

Kamat, N.D. 1962. Chlorophyceae of Ahmedabad, India. Hydrobiol. 20:248-279.

Kargupta, A. N. 1996. Notes on two taxa of Bulbochaete (Chlorophyta: Oedogoniales) from West Bengal, India. Phykos 35:53-56.

Kargupta, A.N. and P. Sarma. 1987. Rare species of Bulbochaete (Chlorophyceae: Oedogoniales) from Birbhum and Murshidabad districts of West Bengal, India. Hydrobiol. 153:13-21.

Kargupta, A.N., D.D. Mukherjee and P. Sarma. 1997. On two new taxa of Bulbochaete (Chlorophyceae: Oedogoniales) from West Bengal, India. Phytomorphol. 47:135-139.

Keshri, J.P. 2008. The genus Bulbochaete C. A. Agardh (Chlorophyta: Oedogoniales) in West Bengal, India. Biblioth. Phycol. 114:103.

Khan, M. 1970. Algal flora of Dehradun-II, Chlorohyceae. GKVJ Sci. Res. 2:87-92.

Mahato, P. and A.K. Mahato. 1999. Some nannandrous species of Bulbochaete from South Bihar, India. Phykos 38:65-70.

Mikulski, J.S. 1982. Biology of Inland Waters. PWN, Warszawa (in Polish). 491 pp.

Naz, S., S.M.G.G. Azam, U. Nahar and N.J. Diba. 2008. Addition to Oedogoniaceous algae of Bangladesh:Bulbochaete Agardh Bangladesh. J. Plant Taxon. 15:81-87.

Prasad, B.N. and T. Fatma. 1981. Bulbochaete ivorensis Gauth-Lièv. A new addition to Indian flora. Curr. Sci. 50:31-32.
Retallack, B. and R.D. Butler. 1970. The development and structure of the zoospore vesicle in Bulbochaete hiloensis. Arch. Mikrobiol. 72:223-237.

Sarma, P. and J.P. Keshri. 1991. Rediscovery of Bulbochaete longipes Bourrelly from India. Crypt. Algol. 12:245-248.

Sarma, P., D.D. Mukherjee and K. Chakraborty. 1988. New records of nannandrous Bulbochaete (Oedogoniales: Chlorophyta) from West Bengal, India. Nova Hedwigia 47:255-267.

Sarma, Y.S.R.K. 1962. On a collection of algae from Rael Tal of district of Varanasi. J. Sci. Res. B.H.U. 13:382-392.

Shukla, H.M. and G.L. Tiwari. 1986. Some macrandrous species of Bulbochaete Agardh from Mauri Lake, Pratapgarh, U.P. Univ. Allahabad Stud. New Ser. 18(4):165-173.

Shukla, H.M., R.K. Tiwari and G.L. Tiwari. 1986. The genus Bulbochaete Agardh (Oedogoniales: Chlorophyta) from Mauri Lake, Pratapgarh, U.P. Res. J. Pl. Environ. 3(1):61-65.

Sinha, S.N. and N. Halder. 2014. New report of Dichotomosiphon tuberosus (A. Br.) Ernst and Vaucheria sessilis DC. of the family Vaucheriaceae from Hooghly district, West Bengal, India. Ecoprint 21:49-53.

Siva, T. and M. Sugumaran. 2013. Physicochemical parameters of marine water from Muthupet mangroves of South East coast of India. IJREB 1(3):40-48.

Srivastava, A.K. and P.K. Misra. 2009. Coleochaete Breb. and Bulbochaete Agardh from North-Eastern Uttar Pradesh, India. Ecoprint 16:59-63.

WHO. 2011. Guidelines for Drinking Water Quality. $4^{\text {th }}$ Eds. World Health Organization, Geneva 27, Switzerland. 